\title{
Perbaikan Keragaan Bibit Jeruk Pamelo 'Nambangan' dengan Strangulasi
}

\author{
Improvement of Pummelo (Citrus grandis (L.) Osbeck) Seedling 'Nambangan' \\ Performance by Strangulation
}

\author{
Wahyu Fikrinda ${ }^{*}$ dan Slamet Susanto ${ }^{2}$
}

Diterima 28 Desember 2016/Disetujui 22 Februari 2017

\begin{abstract}
Pummelo seedling has branches that grow irregularly, stright up, and has less branch. Attempt should be done to stimulate the formation of new branches. The objective of the research was to study the influence of single and double strangulation for stimulation of vegetative growth in order to improve canopy architecture of pummelo seedling. The experiment was conducted from March to September 2011 in green house of Cikabayan Experimental Station IPB, Bogor. Biochemical analysis was done in Laboratory of BALITRO, Bogor and Post-Harvest Laboratory, IPB. The experiment was conducted in Completely Randomized Block Design one factor consisting of 5 treatment: control, single strangulation, double strangulation with distance between wire $5 \mathrm{~cm}$, $10 \mathrm{~cm}$ and $15 \mathrm{~cm}$. The experiment consisted of 5 replicates. There were 25 experimental units. Each experimental unit contained 2 plants and total plants were 50 plants. Strangulation treatment was done in May 19th and wires were removed in August 10th 2011. The results of this research showed that single and double strangulation improved numbers of branch, the lenghth of shoots per plant, numbers of leaf, numbers of scion diameter, volume of canopies andstarch content in leaf. Double strangulation with distance between 2 wires $15 \mathrm{~cm}$ had open canopy and the highest volume of canopies with good canopy appearance at 19 week after application. Strangulation did not cause permanent damage of the sytem tissue and only took two months to recover.
\end{abstract}

Key words: branch, canopy appearance, starch, volume of canopies

\section{ABSTRAK}

Jeruk pamelo memiliki cabang yang tumbuh tidak beraturan, cenderung lurus ke atas dan bercabang sedikit. Upaya untuk merangsang pembentukan cabang baru adalah dengan strangulasi. Tujuan penelitian ini adalah mempelajari pengaruh strangulasi tunggal dan ganda dalam merangsang pertumbuhan vegetatif untuk perbaikan keragaan bibit jeruk pamelo. Percobaan dilaksanakan bulan Maret sampai September 2011 di greenhouse Kebun Percobaan Cikabayan IPB, Bogor. Analisis biokimia dilakukan di Laboratorium Balai Penelitian Tanaman Obat dan Aromatik (BALITRO), Bogor dan Laboratorium Pasca Panen, IPB. Percobaan menggunakan Rancangan Acak Lengkap (RAL) satu faktor sebanyak 5 perlakuan yaitu tanpa strangulasi, strangulasi tunggal dengan ketinggian $5 \mathrm{~cm}$ dari mata tempel, strangulasi ganda dengan jarak antar kawat $5 \mathrm{~cm}, 10 \mathrm{~cm}$ dan 15 $\mathrm{cm}$. Percobaan terdiri atas 5 ulangan dan setiap satu satuan percobaan terdiri atas 2 tanaman sehingga total terdapat 50 tanaman. Aplikasi strangulasi dilaksanakan pada 19 Mei dan kawat dilepas pada 10 Agustus 2011. Hasil penelitian menunjukkan strangulasi tunggal dangan meningkatkan jumlah cabang, panjang cabang per tanaman, jumlah daun, diameter batang, volume tajuk, dan kandungan karbohidrat daun. Aplikasi strangulasi ganda memiliki tajuk terbuka dan volume tajuk terbesar dengan keragaan kanopi yang baik pada 19 minggu setelah perlakuan. Strangulasi tidak memberikan efek merusak secara permanen dan waktu pulihnya hanya dua bulan pada jaringan batang tanaman.

Kata kunci: cabang, karbohidrat, keragaan tajuk, volume kanopi

\footnotetext{
${ }^{1)}$ Program Studi Agroteknologi, Universitas Tribhuwana Tunggadewi Malang

J1. Telaga Warna, Tlogomas, Malang 65144 - Indonesia, Telp. 0341 - 565500, Fax 0341 -565522

${ }^{2)}$ Departemen Agronomi dan Hortikultura, Institut Pertanian Bogor

J1. Meranti, Kampus IPB Darmaga, Bogor 16680, Indonesia

email: fikrindawahyu@yahoo.com (*penulis korespondensi)
} 


\section{PENDAHULUAN}

Jeruk merupakan salah satu buah unggulan nasional Indonesia yang memiliki prospek ekonomi untuk dikembangkan. Indonesia memiliki keanekaragaman hayati yang tinggi sehingga berbagai jenis jeruk dapat tumbuh dan berproduksi dengan baik, seperti jeruk siam, jeruk keprok, jeruk manis, jeruk pamelo, jeruk nipis, dan lain-lain. Jeruk pamelo merupakan tanaman buah asli Indonesia yang banyak dibudidayakan masyarakat karena buahnya enak, penampilannya menarik dan ukuran yang besar. Salah satu varietas jeruk pamelo yang berkembang pesat adalah jeruk Nambangan yang berasal dari Magetan, Jawa Timur. Jeruk ini memiliki banyak keunggulan dibanding jeruk pamelo lainnya yaitu memiliki rasa lebih manis, kulit buahnya lebih tipis dan mudah dipisahkan daging buahnya serta memiliki daya simpan lebih lama (2-3 bulan) (Badan Litbang Pertanian, 2016).

Keragaan bibit tanaman yang baik dapat dilihat dari pertumbuhan yang baik dan bibit memiliki struktur kanopi yang kompak dan vigor (Aliyah et al., 2015). Sistem tajuk yang terbentuk dengan baik akan memaksimalkan penyerapan sinar matahari dalam berfotosintesis sehingga pohon menjadi kokoh dan dapat berproduksi tinggi (Gilman dan Black, 2011). Pohon dengan volume kanopi yang lebih besar memiliki indeks luas daun lebih besar dan menghasilkan jumlah asimilat yang lebih banyak dan akan mendukung produksi buah yang banyak (Shafiezargar et al., 2012). Beberapa usaha memanipulasi keragaan tanaman untuk membentuk arsitektur tajuk menjadi lebih terbuka adalah dengan pelatihan batang utama, penjarangan dan perundukan cabang. Kendala fisik jeruk pamelo sampai saat ini yaitu memiliki cabang yang tumbuh tidak beraturan, cenderung lurus ke atas dan bercabang sedikit (Santoso et al., 2009). Adanya manipulasi keragaan tanaman muda perlu dilakukan dengan cara baru sehingga diperoleh tajuk yang terbuka dan kokoh sejak awal pertumbuhan bibit.

Strangulasi merupakan alternatif yang dapat dilakukan untuk merangsang pembentukan cabang dalam meningkatkan keragaan bibit pamelo. Strangulasi adalah pengikatan batang menggunakan kawat sampai pembuluh floem untuk menghambat translokasi fotosintat dari tajuk menuju akar pada jangka waktu tertentu.
Menurut Susanto et al. (2002) adanya hambatan translokasi karbohidrat ke akar menyebabkan akar kekurangan fotosintat dan respirasi akar menurun sehingga aktivitas akar dalam mengabsorpsi hara dan mineral terganggu. Menurut Thamrin et al. (2009) penurunan aktivitas akar akan berdampak pada peningkatan rasio $\mathrm{C} / \mathrm{N}$ di tajuk yang dapat memunculkan tunas baru, pembentukan bunga dan perkembangan buah.

Sampai saat ini, strangulasi pada tanaman muda belum banyak dilakukan. Strangulasi pada tanaman muda dapat memudahkan pembentukan arsitektur tanaman sejak terbentuknya cabang primer yang kokoh dan terbuka. Menurut Susanto dan Supriyanto (2005) produktivitas tanaman sangat dipengaruhi oleh luas bagian tajuk yang terkena sinar matahari. Penelitian bertujuan untuk mempelajari pengaruh strangulasi dalam merangsang pembentukan cabang dalam memperbaiki keragaan bibit jeruk pamelo varietas Nambangan.

\section{BAHAN DAN METODE}

Percobaan dilaksanakan pada bulan Maret sampai September 2011 di greenhouse Kebun Percobaan Cikabayan, Dramaga, Institut Pertanian Bogor. Pengikatan kawat dilakukan secara serentak pada 18 Mei 2011 dan pelepasan kawat dilakukan pada tanggal 11 Agustus 2011. Analisis hara dilakukan di Laboratorium Balai Penelitian Tanaman Obat dan Aromatik (BALITRO), Cimanggu Bogor. Analisis brangkasan dilakukan di Laboratorium Pasca Panen, Departemen Agronomi dan Hortikultura, IPB. Bahan tanaman yang digunakan adalah 50 bibit jeruk pamelo varietas Nambangan hasil okulasi berumur 6 bulan. Bahan untuk strangulasi yaitu kawat putih berdiameter $1 \mathrm{~mm}$. Bahan untuk media tumbuh yaitu pasir, tanah, pupuk kandang $(2: 1: 1)(\mathrm{V}: \mathrm{V}: \mathrm{V})$, polibag ukuran $35 \mathrm{~cm} \times 30$ $\mathrm{cm}$. Bahan untuk pemeliharaan tanaman yaitu pupuk organik granul ( $0.5 \mathrm{~kg}$ tiap polibag), pupuk NPK mutiara $15-15-15\left(15 \mathrm{~g} \mathrm{~L}^{-1}\right.$ air), pupuk ZA (15 $\mathrm{g} \mathrm{L}^{-1}$ air), pupuk gandasil daun,

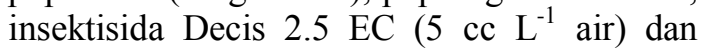
paranet $40 \%$.

Percobaan menggunakan Rancangan Acak Lengkap (RAL) satu faktor. Percobaan terdiri atas lima perlakuan, yaitu T0: tanpa 
strangulasi, T1: strangulasi tunggal dengan ketinggian $5 \mathrm{~cm}$ dari mata tempel, T2: strangulasi gandadengan jarak $5 \mathrm{~cm}$ antar kawat dan ketinggian $5 \mathrm{~cm}$ dari mata tempel, T3: strangulasi ganda dengan jarak $10 \mathrm{~cm}$ antar kawat dan ketinggian $5 \mathrm{~cm}$ dari mata tempel, T4: strangulasi ganda dengan jarak 15 $\mathrm{cm}$ antar kawat dan ketinggian $5 \mathrm{~cm}$ dari mata tempel. Pengolahan data dilakukan dengan menggunakan sidik ragam dan uji Duncan Multiple Range Test (DMRT). Seluruh proses analisis data dilakukan dengan menggunakan perangkat lunak SAS System for Windows versi 9.13 .

Tahapan percobaan ini adalah persiapan media tanaman, pemilihan bibit dan aplikasi strangulasi. Bibit yang digunakan merupakan hasil seleksi perbanyakan okulasi yang memiliki pertumbuhan seragam dan sehat. Strangulasi dilaksanakan dengan melilitkan kawat berdiameter $1 \mathrm{~mm}$ pada batang dengan menekan kawat ke batang sedalam diameter kawat tersebut. Pelepasan kawat dilakukan setelah batang distrangulasi selama tiga bulan dengan menghilangkan kalus terlebih dahulu.

Pemeliharaan meliputi pemupukan, penyiraman, pengendalian hama dan penyakit, pemangkasan dan pemberian naungan. Pemupukan NPK Mutiara (15-15-15) dan ZA dilakukan tiap dua minggu sekali dengan konsentrasi $15 \mathrm{~g} \mathrm{~L}^{-1}$, tiap tanaman memperoleh $100 \mathrm{~m} \mathrm{~L}$ (Sutopo et al., 2005). Pemupukan organik granul diberikan 500 g per tanaman dan disebarkan di atas media tanam. Penyiraman dilakukan tiap pagi dan sore hari dengan volume air $1 \mathrm{~L}$ per tanaman. Pemangkasan tunas adventif dan tunas samping dilakukan pada saat sebelum aplikasi strangulasi serta pemangkasan tunas pucuk dilakukan serentak setelah pelaksanaan strangulasi. Pengendalian OPT secara kimia dilakukan tiap satu bulan sekali dengan menyemprotkan insektisida Decis 2.5 EC ( 5 cc $\mathrm{L}^{-1}$ air).

Pengamatan dilakukan tiap dua minggu sekali dimulai sejak satu minggu setelah aplikasi strangulasi sampai dua bulan setelah strangulasi dilepas. Peubah pengamatan terdiri atas jumlah cabang (cabang), panjang rata-rata cabang per tanaman (cm), jumlah daun (daun), luas daun $\left(\mathrm{cm}^{2}\right)$, diameter batang $(\mathrm{mm})$ diukur dengan jangka sorong, volume tajuk $\left(\mathrm{cm}^{3}\right)$ dilakukan dengan mengukur panjang dan lebar tajuk serta tinggi tanaman dari pangkal batangnya, karbohidrat daun (\%), bobot basah dan kering akar dan tajuk tanaman (g). Pengamatan luas daun $\left(\mathrm{cm}^{2}\right)$ diukur tiap bulan dengan metode gravimetri (perbandingan bobot). Pengamatan bobot basah dan kering akar dan tajuk dilakukan secara destruktif pada akhir penelitian terhadap 10 tanaman contoh. Tanaman dikeringkan dalam oven pada suhu $70{ }^{0} \mathrm{C}$ selama48 jam. Analisis kandungan karbohidrat pada daun menggunakan metode Semogyi Nelson sedangkan kandungan nitrogen menggunakan metode semi-mikro Kjedahl (Yoshida et al., 1972).

\section{HASIL DAN PEMBAHASAN}

Pengaruh strangulasi tidak berakibat buruk terhadap pertumbuhan bibit pamelo dengan kondisi bekas luka setelah kawat dilepas cukup baik. Selama penelitian, tanaman tidak mengalami gangguan abiotik (cekaman air dan cekaman hara) dangan gangguan biotik (serangan hama dan penyakit). Suhu di dalam rumah kaca berkisar antara 21.8 sampai $36{ }^{\circ} \mathrm{C}$ pada pagi sampai sore hari.

\section{Jumlah Cabang}

Strangulasi meningkatkan jumlah cabang vegetatif pada 9 sampai 15 MSP. Aplikasi strangulasi ganda dengan jarak $10 \mathrm{~cm}$ (T3) pada 13 sampai 19 MSP memiliki jumlah cabang yang tidak berbeda dengan kontrol (T0) tetapi berbeda dengan aplikasi strangulasi tunggal dan perlakuan strangulasi ganda dengan jarak $5 \mathrm{~cm}$ (T2) dan $15 \mathrm{~cm}$ (T4) (Gambar 1).

Perkembangan cabang pada tanaman tanpa strangulasi berbeda dengan aplikasi strangulasi yaitu tanaman tanpa strangulasi (T0) perkembangan dimulai dengan pertumbuhan ke atas dari pucuk terminal. Akibatnya jumlah tunas samping yang terbentuk lebih sedikit dibandingkan dengan tanaman strangulasi yang terlihat mulai 7 MSP. Pada 13 MSP sampai 19 MSP, jumlah tunas samping tanaman kontrol mulai meningkat dan tidak berbeda dengan perlakuan T3. 

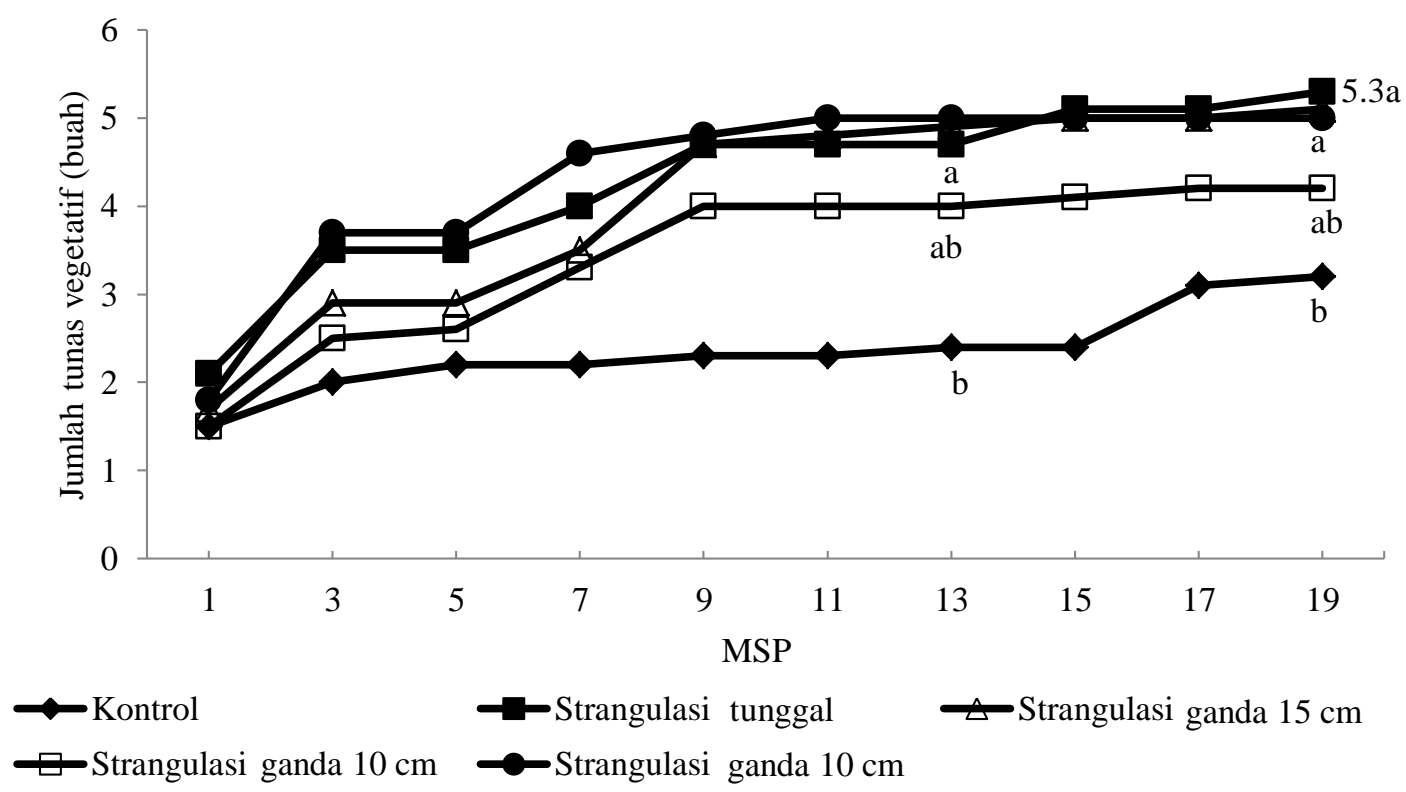

Gambar 1. Perkembangan jumlah cabang vegetatif pada 1-19 MSP

Tunas samping pada strangulasi tunggal banyak terbentuk di bagian bawah perlakuan strangulasi. Tunas samping yang tumbuh baik di bawah strangulasi dapat dijadikan alternatif cabang sekunder pada bibit pamelo. Hal ini sejalan dengan penelitian Magda et al. (2015) bahwa efek girdling akan terlihat dari bagian bawah perlakuan girdling. Akibat adanya pengikatan kawat, hormon auksin yang seharusnya bergerak dari atas ke bawah terhambat dan bergerak ke tunas samping. Transport auksin berlangsung secara basipetal yaitu dari ujung ke basal. Transport auksin tersebut terkait dengan pembentukan cabang di bagian bawah yang jauh lebih panjang dibandingkan dengan cabang yang terbentuk di bagian tengah dan atas strangulasi.

\section{Panjang Cabang per Tanaman}

Strangulasi meningkatkan panjang cabang per tanaman pada $11,13,17$ dan 19 MSP (Gambar 2). Pada 11-19 MSP perlakuan kontrol memiliki panjang cabang rata-rata tertinggi dan berbeda dengan perlakuan strangulasi tunggal maupun ganda.



Gambar 2. Perkembangan panjang cabang per tanaman pada 1-19 MSP 
Hasil penelitian ini berbeda dengan penelitian Cotut dan Stanica (2015) bahwa panjang cabang tanaman buah Chinese Date yang telah menghasilkan, meningkat tajam dibandingkan dengan kontrol. Hal ini mengindikasikan bahwa pemanjangan cabang baru akan aktif dengan adanya aplikasi girdling pada tanaman buah menghasilkan, sedangkan pada bibit pamelo ini, aplikasi strangulasi menstimulasi munculnya cabang yang lebih banyak dibandingkan dengan pemanjangan cabang.

\section{Jumlah Daun}

Strangulasi meningkatkan jumlah daun total per tanaman pada 3 sampai 15 MSP (Gambar 3). Aplikasi strangulasi ganda dengan jarak $15 \mathrm{~cm}$ (T4) memberikan jumlah daun tertinggi mulai dari 3 sampai 19 MSP dan berbeda dengan kontrol namun tidak berbeda dengan aplikasi strangulasi tunggal dan ganda dengan jarak $5 \mathrm{~cm}$ (T2) dan $10 \mathrm{~cm}$ (T3).
Banyaknya jumlah daun dan luas daun akan berpengaruh terhadap fotosintat yang dihasilkan. Semakin besar tanaman menyerap cahaya untuk fotosintesis maka fotosintat yang dihasilkan semakin tinggi yang akan mempengaruhi terbentuknya tunas baru (Glenn dan Campostrini, 2011; Jana, 2015). Cadangan karbohidrat selain untuk pembungaan, pembentukan buah juga dapat digunakan dahulu bagi pertumbuhan vegetatif tanaman (Liu et al., 1999).

\section{Diameter Batang}

Strangulasi memperbesar diameter batang atas tanaman mulai 3 minggu setelah perlakuan (MSP) sampai dengan 19 MSP dan berbeda disbanding kontrol. Aplikasi strangulasi ganda dengan jarak $15 \mathrm{~cm}$ (T4) menghasilkan diameter batang paling besar $(1.33 \mathrm{~cm})$ dan tidak berbeda dengan kontrol (T0) $(1.11 \mathrm{~cm})$ namun berbeda dengan aplikasi lainnya (Gambar 4).

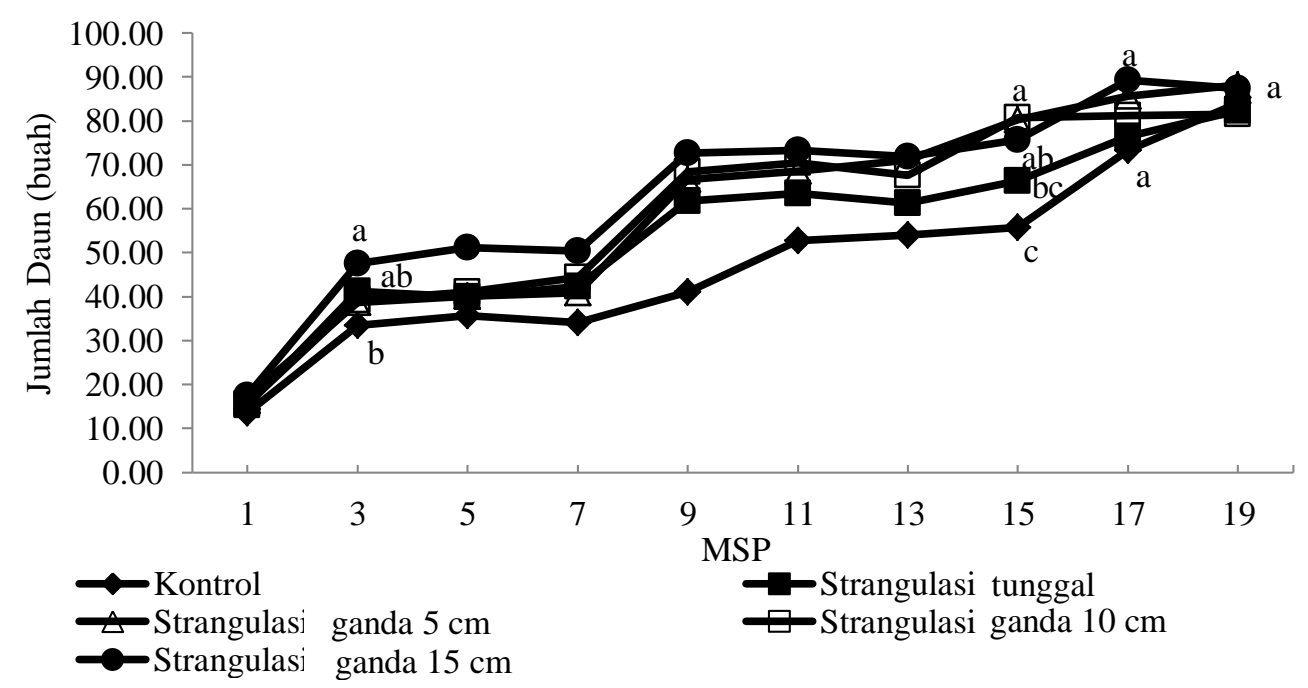

Gambar 3. Perkembangan jumlah daun pada 1-19 MSP 


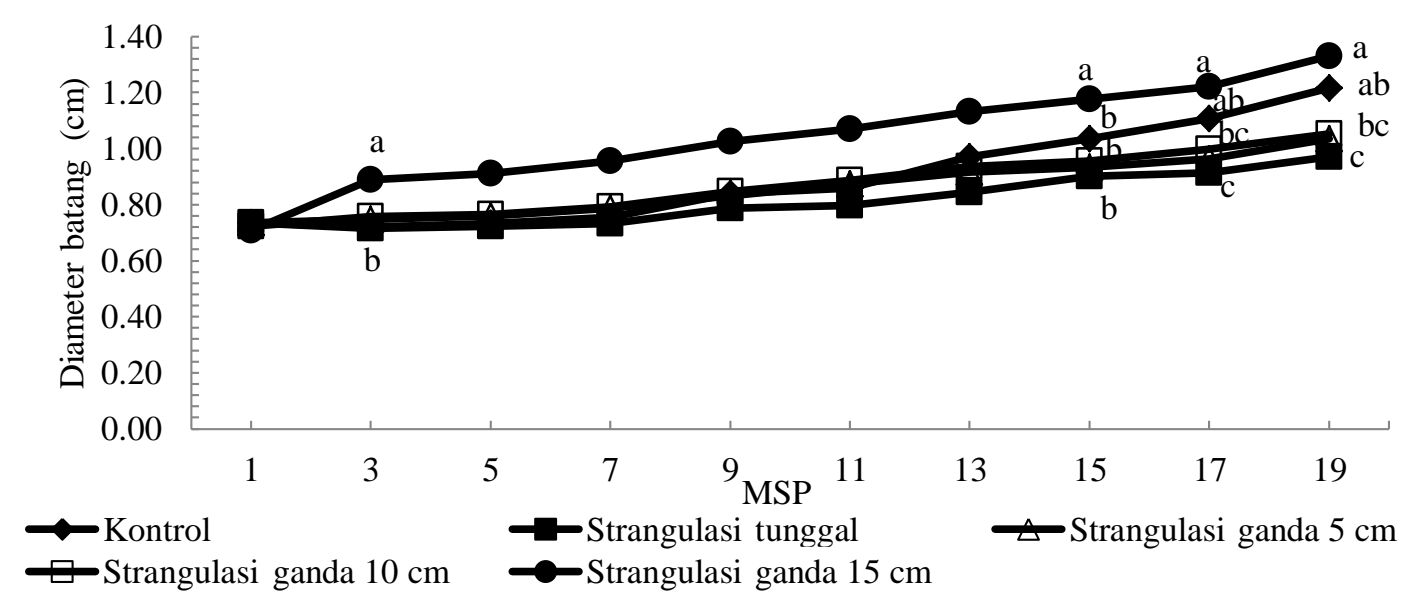

Gambar 4. Perkembangan diameter batang pada 1-19 MSP

Tanaman kontrol (T0) dari minggu ke minggu mengalami peningkatan diameter batang yang tinggi namun tidak berbeda dengan aplikasi strangulasi ganda dengan jarak $15 \mathrm{~cm}$. Tanaman kontrol mengalami pembentukan cabang samping yang sedikit sehingga asimilat difokuskan untuk pembesaran diameter cabang.

\section{Volume Tajuk}

Strangulasi meningkatkan volume tajuk bibit jeruk pamelo pada 1 MSP sampai 17 MSP, kecuali pada 5 MSP (Gambar 5). Perlakuan yang memiliki volume tajuk yang tertinggi terdapat pada perlakuan strangulasi ganda dengan jarak $15 \mathrm{~cm}\left(223239 \mathrm{~cm}^{3}\right)$ yang berbeda dengan kontrol $\left(104831 \mathrm{~cm}^{3}\right)$.

Berdasarkan data volume tajuk, aplikasi strangulasi tunggal dan ganda mampu membentuk tajuk terbuka. Aplikasi strangulasi ganda dengan jarak $15 \mathrm{~cm}$ (T4) memiliki ukuran volume terbesar dan terbuka dengan arsitektur kanopi yang baik sehingga tanaman tidak terlalu rimbun dan cahaya dapat masuk ke bagian dalam tajuk bibit jeruk. Berdasarkan penelitian Aliyah et al. (2015) aplikasi strangulasi ganda dengan pinching memiliki bobot basah dan kering kanopi terbesar dengan jumlah daun, luas daun serta diameter batang terbesar dibandingkan perlakuan lainnya. Sedangkan penelitian Susanto et al. (2016) strangulasi ganda lebih efektif dalam meningkatkan pembungaan dibandingkan dengan srangulasi tunggal.

Pembentukan arsitektur kanopi yang baik dapat meningkatkan efisiensi pemanenan energi matahari, mengendalikan pertumbuhan dan perkembangan tanaman. Menurut Anten (2016) terdapat beberapa hal yang dapat mengoptimalkan fotosintesis pada kanopi yaitu memaksimalkan fotosintesis untuk investasi biomassa pada daun dan untuk memberikan kandungan total nitrogen yang tinggi. Peltoniemi et al. (2012) menyatakan, hal yang dapat mengoptimalkan fotosintesis yaitu memaksimalkan fotosintesis kanopi dengan pemberian nitrogen dan penggunaan air.

\section{Karbohidrat Daun}

Strangulasi meningkatkan kandungan karbohidrat daun dan kandungan $\mathrm{C} / \mathrm{N}$ (Tabel 1). Strangulasi tunggal (T1) memiliki persentase karbohidrat tertinggi (13.46\%) dan tidak berbeda dengan aplikasi strangulasi ganda dengan jarak $5 \mathrm{~cm}$ (T2) (11.94\%), 10 cm (T3) (9.87\%) dan $15 \mathrm{~cm}$ (T4) (12.16\%), namun berbeda dengan kontrol (T0) $(6.22 \%)$. Berdasarkan hasil rasio $\mathrm{C} / \mathrm{N}$ daun, aplikasi strangulasi tunggal memiliki rasio $\mathrm{C} / \mathrm{N}$ tertinggi yaitu sebesar 4.97 dan tidak berbeda dengan perlakuan strangulasi yang lainnya. 


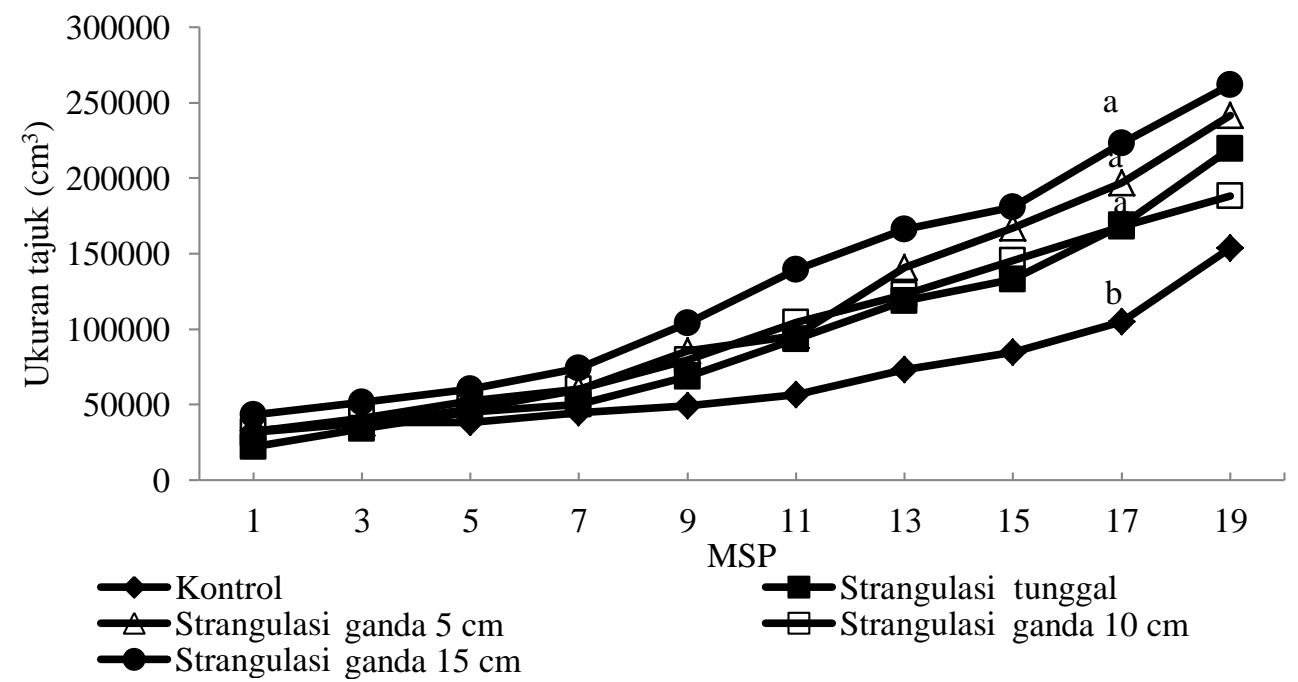

Gambar 5. Perkembangan volume tajuk pada 1-19 MSP

Tabel 1. Kandungan karbohidrat, nitrogen, $\mathrm{C} / \mathrm{N}$ daun pada saat pelepasan kawat (13 MSP)

\begin{tabular}{lccc}
\hline \multicolumn{1}{c}{ Perlakuan } & Karbohidrat $(\%)$ & Nitrogen $(\%)$ & C/N \\
\hline Kontrol & $6.22 \mathrm{c}$ & $3.26 \mathrm{a}$ & $1.92 \mathrm{c}$ \\
Strangulasi Tunggal & $13.46 \mathrm{a}$ & $2.71 \mathrm{a}$ & $4.97 \mathrm{a}$ \\
Strangulasi Ganda $5 \mathrm{~cm}$ & $11.94 \mathrm{ab}$ & $3.10 \mathrm{a}$ & $3.86 \mathrm{~b}$ \\
Strangulasi Ganda $10 \mathrm{~cm}$ & $9.87 \mathrm{~b}$ & $2.74 \mathrm{a}$ & $3.61 \mathrm{~b}$ \\
Strangulasi Ganda $15 \mathrm{~cm}$ & $12.16 \mathrm{ab}$ & $2.92 \mathrm{a}$ & $4.17 \mathrm{ab}$ \\
\hline
\end{tabular}

Keterangan: Nilai yang diikuti dengan huruf yang sama pada kolom yang sama berarti tidak berbeda nyata menurut uji DMRT pada taraf $=5 \%$.

Strangulasi meningkatkan kandungan karbohidrat pada daun bagian atas luka (Thamrin et al., 2009; Susanto et al., 2016). Aplikasi girdling juga terbukti meningkatkan konsentrasi karbohidrat di bawah bagian luka (Raffo et al., 2011; Magda et al., 2015) dan beberapa minggu sebelum berbunga mengurangi absisi pada buah jeruk dan meningkatkan kandungan klorofil (Rivas et al., 2008). Adanya kandungan klorofil yang tinggi ini akan meningkatkan fotosintat yang terbentuk pada bagian atas strangulasi. Akumulasi karbohidrat daun di bagian tajuk yang diikuti dengan berkurangnya absorpsi hara mineral terutama nitrogen yang akan meningkatkan nisbah $\mathrm{C} / \mathrm{N}$ tajuk. Peningkatan nisbah $\mathrm{C} / \mathrm{N}$ ini menyebabkan bibit jeruk lebih banyak membentuk tunas terutama pada perlakuan yang memiliki hasil nisbah $\mathrm{C} / \mathrm{N}$ tinggi.

\section{Bobot Basah dan Bobot Kering Akar dan Tajuk}

Strangulasi tidak meningkatkan bobot basah dan kering akar. Pada tanaman kontrol (T0) dan aplikasi strangulasi tunggal (T1) memiliki akar yang lebih lebat dibandingkan strangulasi ganda dengan jarak antar kawat 5 $\mathrm{cm}$ (T2), $10 \mathrm{~cm}$ (T3) dan $15 \mathrm{~cm}$ (T4). Adanya aplikasi strangulasi akan menurunkan pertumbuhan akar sehingga aktivitas pada akar juga menurun. Hal ini sejalan dengan penelitian Santos et al. (2014) bahwa girdling dapat mengurangi pertumbuhan akar dan secara bersamaan mengurangi penyerapan hara dari tanah. 
Tabel 2. Bobot basah dan kering akar pada 19 MSP

\begin{tabular}{lcccc}
\hline \multicolumn{1}{c}{ Perlakuan } & BB Akar $(\mathrm{g})$ & BK Akar $(\mathrm{g})$ & BB Tajuk $(\mathrm{g})$ & BK Tajuk $(\mathrm{g})$ \\
\hline Kontrol & 36.66 & 17.19 & 108.23 & 54.22 \\
Strangulasi Tunggal & 35.27 & 20.88 & 103.65 & 57.89 \\
Strangulasi Ganda jarak 5 cm & 31.70 & 17.35 & 123.58 & 62.01 \\
Strangulasi Ganda jarak 10 cm & 23.04 & 13.69 & 79.03 & 47.02 \\
Strangulasi Ganda jarak 15 cm & 29.99 & 16.47 & 158.34 & 70.02 \\
\hline
\end{tabular}

Keterangan: Nilai yang diikuti dengan huruf yang sama pada kolom yang sama berarti tidak berbeda nyata menurut uji DMRT pada taraf $5 \%$.

Strangulasi tidak meningkatkan bobot basah dan kering tajuk. Perlakuan kontrol dan strangulasi memiliki bentuk tajuk yang berbeda dimana pada perlakuan kontrol terjadi dominansi apikal yang terlihat dari tinggi tajuk lebih tinggi, bercabang sedikit dan daun di bagian atasnya lebar dibandingkan dengan bibit jeruk dengan aplikasi strangulasi. Strangulasi ganda memiliki tajuk yang rimbun dengan bentuk tajuk terbuka.

\section{Efek Strangulasi}

Kalus mulai terbentuk satu minggu setelah kawat strangulasi dilepas. Pada waktu empat minggu setelah kawat dilepas, luka telah tertutup dan delapan minggu setelahnya luka tertutup sempurna (Gambar 6). Strangulasi tidak memberikan efek merusak secara permanen pada jaringan tanaman dan hanya membutuhkan waktu dua bulan untuk pulih kembali.



Gambar 6. Batang bibit pamelo yang telah pulih setelah aplikasi strangulasi

\section{KESIMPULAN}

Strangulasi tunggal dan ganda meningkatkan jumlah cabang, panjang cabang per tanaman, jumlah daun, diameter batang, volume tajuk, dan kandungan karbohidrat daun. Aplikasi strangulasi ganda lebih baik dibanding strangulasi tunggal karena memiliki ukuran tajuk terbesar dan terbuka dengan arsitektur kanopi yang baik. Strangulasi tidak memberikan efek merusak secara permanen dan waktu pulihnya hanya dua bulan pada jaringan batang tanaman.

\section{DAFTAR PUSTAKA}

Aliyah, M., S. Susanto, D. Sukma, S.W. Ardie. 2015. Performance improvement of young pummelo citrus (Citrus maxima (Burm.) Merr.) by strangulation application and pinching. Asian J. Agric. Res. 9(2): 77-83.

Anten, N.P.R. 2016. Optimization and game theory in canopy models.p.355-377. In K. Hikosaka, €.U.Niinemets, N. Anten (eds.). Canopy Photosynthesis: From Basics to Applications. Springer, Berlin.

[Balitbangtan] Badan Litbang Pertanian. 2016. Varietas: pamelo nambangan. http:// www.litbang.pertanian.go.id/varietas/on e/995/. [25 Agustus 2016].

Cotrut, R., F. Stanica. 2015. Effect of tree girdling on some varieties of Chinese date (Ziziphus jujuba Mill.). Horticulture. 55: 37-42.

Gilman, E.F., R.J. Black. 2011. Pruning landscape trees and shrubs. University of Florida. 863:1-13.

Glenn, D.M., E. Campostrini. 2011. Girdling and summer prunning in apple increase soil respiration. Scientia Horticulturae. 129(4): 889-893. 
Jana, B.R. 2015. Induction of flowering in asian pear (Pyrus spp.) a review. Intl. j. plant research. 5(3): 57-63.

Liu, X., P.N. Robinson, M.A. Madore, G.W Witney, M.L. Arpaia. 1999. 'Hass' avocado carbohydrate fluctuations. I. Growth phenology. J. Amer. Soc. Hort. Sci. 124(6): 671-675.

Magda, M.N., H.S. Naglaa, A. Samia, Asad, S.A. Atalla. 2015. Effect of some horticultural practices on fruit set, yield and quality of "Le-Conte" pear trees. Middle East J. Appl. Sci. 5(4): 11151127.

Peltoniemi, M., R. Duursma, B. Medlyn. 2012. Co-optimal distribution of leaf nitrogen and hydraulic conductance in plant canopies. Tree Physiol. 32: 510-519.

Raffo, M.D., P. Cairo, V. Angelis, L. Manuec, S. Ziaurriz, F. Menni. 2011. Effect of trunk girdling on fruit production, fruit size and tree vigor on "Bartlett" pear in Rio Negro and Neuquen valley, Argentina. Acta Horticulture. 909: 645650 .

Rivas, F., F. Fernando, M. Agusti. 2008. Girdling induce oxidative damage and triggers enzymatic and non-enzymatic antioxidative defences in Citrus leaves. Environ. Exp. Bt. 64: 256-263.

Santoso, A.P., N. Hayati, S.E. Haryanti, R.T.R. Pinem. 2009. Sertifikasi Benih Jeruk. Direktorat Perbenihan dan Sarana Produksi Direktorat Jenderal Hortikultura.
Shafieizargar, A., Y. Awang, A.S. Juraimi, R. Othman. 2012. Yield and fruit quality of 'Queen' orange (Citrus sinensis (L) Osb.) graftedon different rootstocks in Iran. AJCS. 6(5): 777-783.

Susanto, S., S. Minten, A. Mursyada. 2002. Pengaruh strangulasi terhadap pembungaan jeruk besar (Citrus grandis (L.) Osbeck) kultivar Nambangan. J. Agrotropika. 7(1): 57-63.

Susanto, D.A., A. Supriyanto. 2005. Teknik pemangkasan pemeliharaan tanaman jeruk. Citrusindo.1: 1-2.

Susanto, S., M. Melati, H. Sugeru. 2016. Perbaikan pembungaan pamelo melalui aplikasi strangulasi dan zat pemecah dormansi. J. Hort. Indonesia. 7(3): 139145.

Sutopo, A. Supriyanto, A. Sugiyatno. 2005. Penetapan Nilai Standar Hara Makro pada Daun untuk Rekomendasi Pemupukan pada Tanaman Pamelo. Prosiding Seminar Nasional Jeruk Tropika Indonesia. 235-241.

Thamrin, M., S.Susanto, E. Santosa. 2009. The effectivity of strangulation to pummelo Cikoneng flowering (Citrus grandis (L.) Osbeck) at different fruit level previously. J. Agron. Indonesia. 37(1): 40-45.

Yoshida, S., D.A. Forno, J.H. Cock, K.A. Gomes. 1972. Laboratory Manual Physiological Studies of Rice. Second Edition. IRRI, Los Banos, Philippines. 